Dr SLOBODAN SELINIĆ, naučni savetnik

Institut za noviju istoriju Srbije

Beograd, Republika Srbija

UDK 323(497.1)"1982/1983"(093.2)

slobodanselinic@gmail.com

32:929 Ранковић А.

originalan naučni rad / original scientific paper

primljeno / received: 21. 11. 2020.

prihvaćeno / accepted: 19. 5. 2021.

https://doi.org/10.29362/ist20veka.2021.2.sel.415-434

\title{
SRBIJA I POLITIČKI ODNOSI U JUGOSLAVIJI U VREME SAHRANE ALEKSANDRA RANKOVIĆA 1983: TAČKE SUKOBA
}

APSTRAKT: U uslovima duboke ekonomske krize, posledica albanske pobune na Kosovu 1981. i sve očitijih slabosti društveno-ekonomskog i političkog sistema, političke krize i sporovi u posletitovskoj Jugoslaviji su bili neretka pojava. Tokom 1983. između rukovodstava Srbije i drugih republika, ali i srpskih pokrajina, izbilo je više nesaglasnosti, pre svega oko odgovornosti za politički neželjene pojave na sahrani Aleksandra Rankovića, pitanja izbora Draže Markovića za predsednika Predsedništva CK SKJ i sprečavanja objavljivanja knjiga koje je vlast ocenila kao politički nepoželjne.

KLJUČNE REČI: Srbija, Jugoslavija, Hrvatska, Bosna i Hercegovina, politika, Aleksandar Ranković, Ivan Stambolić, Savez komunista Jugoslavije

Političke odnose Srbije i drugih republika ili federacije obeležilo je tokom 1983. više kriza i sporova. Te godine Jugoslavija je bila zemlja u kojoj je politička, ekonomska i društvena kriza bila evidentna. Od samoupravnog sistema nije ostalo mnogo osim partijskih referata i programa. Jugoslavija je bila država bez jedinstvenog tržišta. Spoljni dug zemlje je postao opšte poznati problem i prema zvaničnim podacima od 1976. do 1984. porastao je sa 7,9 milijardi na 20,1 milijardu dolara. ${ }^{1}$ Član Predsedništva CK SKS Slobodan Milošević je na sednici CK SKS oko dva meseca pre smrti Aleksandra Rankovića ozbiljnost situacije ilustrovao podatkom da je u 1982. godini 78\% ukupnog deviznog priliva Jugoslavije ostvarenog izvozom otišlo na otplatu dugova inostranstvu. ${ }^{2}$ Jugoslavija je između proglašavanja moratorijuma i sklapanja aranžmana sa stranim finansijskim institucijama izabrala drugu opciju. Pregovorima sa MMF-om, Međunarodnom bankom za obnovu i razvoj, Bankom za međunarodne obračune iz Bazela, petnaest zapadnih vlada i oko 600 komercijalnih banaka dotadašnjih

\footnotetext{
${ }^{1}$ Arhiv Srbije (AS), fond G-274, Predsedništvo SR Srbije, 1985, 25 - 400, dokument 30 - 765/85.

2 AS, fond Đ-2, CK SKS, kutija 396, 1983, Materijali sa 10. sednice CK SKS, održane 30. juna 1983, Strogo poverljivo, Zatvoreni deo sednice.
} 
kreditora jugoslovenske privrede koje su formirale Međunarodni koordinacioni komitet od 15 banaka, zaključeni su aranžmani o pet kreditnih linija vrednih oko 4,5 milijarde dolara kojima je Jugoslavija 1983. održala spoljnu likvidnost. Zakoni kojima je omogućen sporazum sa stranim finansijskim institucijama usvojeni su na dramatičnoj noćnoj sednici Savezne skupštine 2/3. jula 1983. na kojoj je predsednica SIV-a Milka Planinc pretila moratorijumom u slučaju neusvajanja predloga njene vlade. Dugoročni program ekonomske stabilizacije iz leta 1983, kao odgovor na krizu, nije dao rezultate. ${ }^{3}$ Nezaposlenost je bila preokupacija omladine. Krajem juna 1983. nezaposlenih je u Srbiji bilo 439.146, od čega u centralnom delu republike 270.278, Vojvodini 86.233, na Kosovu 82.675. Trećina nezaposlenih Jugoslovena bila je u centralnoj Srbiji. ${ }^{4}$

Razjedinjenost političkog rukovodstva zemlje iskazana je, između ostalog, i sukobima oko izbora predsednika Predsedništva CK SKJ 1981. i izbora Dragoslava Draže Markovića u to telo 1982. ${ }^{5}$ Republičko rukovodstvo Srbije i pokrajinski političari bili su podeljeni oko tumačenja odnosa u Srbiji, a do leta 1983. proteklo je već dve godine od kako je Srbija, posle albanske pobune u SAP Kosovu 1981, iznova otvorila pitanje neravnopravnog položaja u federaciji i političke, pravne, ekonomske i kulturne dezintegracije republike posle Ustava iz 1974. ${ }^{6}$ Očevidna nesposobnost i neodlučnost vlasti da se obračuna sa separatizmom u južnoj pokrajini i zaštiti Srbe i Crnogorce, podgrevana tekstovima u štampi o stradanju srpskog naroda, jačala je nacionalna osećanja Srba i stvarala revolt u narodu. Nacionalne tenzije su se iz pokrajine prelivale u unutrašnjost Srbije, pa je republički vrh počeo da se bavi i teškim stanjem u Preševu, Buja-

\footnotetext{
${ }^{3}$ AS, G-274, Predsedništvo SR Srbije, 1985, 25 - 400, dokument 30 - 765/85; Arhiv Jugoslavije (AJ), fond 507, Savez komunista Jugoslavije (SKJ), Predsedništvo CK SKJ, 49. sednica, 24. 10. 1983, SIV, 114/83, Državna tajna, polazne osnove; Dejan Jović, Jugoslavija - država koja je odumrla. Uspon, kriza i pad Četvrte Jugoslavije (1974.-1990.), (Zagreb-Beograd: PrometejSamizdat B92, 2003), 237.

${ }^{4}$ AS, Đ-2, CK SKS, kutija 418, 1983, Materijali sa 55. sednice Predsedništva CK SKS, održane 26. decembra 1983, Aktuelni problemi u oblasti socijalnih razlika...

${ }^{5}$ Mirko Đekić, Upotreba Srbije. Optužbe i priznanja Draže Markovića (Beograd: Beseda, 1990); Душан Чкребић, Поглед искоса (Београд: Службени гласник, 2009), 214; Kosta Nikolić, „Kako je Slobodan Milošević izabran za vođu srpskih komunista“, Istorija 20. veka, br. 1, (2006), 9-26.

6 Љубодраг Димић, Историја српске државности, III, Србија у Југославији (Нови Сад: Српска академија наука и уметности (огранак у Новом Саду), „Беседа“, издавачка установа православне епархије Бачке и Друштво историчара јужнобачког и сремског округа, 2011); Mile Bjelajac, „Proizvođenje novih nacija, novih manjina i teritorijalna pitanja. (Koncept konkurentske države na tlu Srbije)“, The Shared History. Nations, States and Diasporas of the Former Yugoslavia (Nacije, države i dijaspora na prostoru bivše Jugoslavije), glavni i odgovorni urednik Darko Gavrilović (Sremska Kamenica: Institute for Historical Justice and Reconciliation, Fakultet za evropske pravno-političke studije, 2010), 121-142; Slobodan Bjelica, "Views of Vojvodinian Leadership on Re-opening the Issue of the Relationship Between SR Serbia and SAP Vojvodina in 1981", Istraživanja, br. 27, (2016), 258-273; Слободан Бјелица, „Војвођанска аутономија - кризно жариште социјалистичке Југославије“, Култура полиса, посебно издање Војводина као потенцијално геополитичко жариште у Републици Србији, приредили Љубиша Деспотовић и Горан Иванчевић, (Нови Сад: Култура - Полис, Институт за европске студије, 2018), 273-280.
} 
novcu i Medveđi i masovnim iseljavanjem Srba iz tih opština. ${ }^{7}$ Sukob sa delom intelektualaca je trajao godinama, a hapšenjem Gojka Đoga krug protivnika u toj populaciji samo je proširen. ${ }^{8}$

$$
* * *
$$

Prve velike političke krize u federaciji posle Titove smrti bile su vezane za postavljanje pitanja položaja Srbije prema Ustavu iz 1974. i odnosa republike i pokrajina. Ti problemi su se prelamali preko izbora predsednika Predsedništva CK SKJ i člana iz Srbije u tom telu tokom 1982. Srbija je, uprkos velikih otpora iz pokrajina, BiH i Hrvatske, uspela da spreči da na čelo Predsedništva CK SKJ bude izabran Miloš Minić, kao političar koji nije imao podršku rukovodstva Srbije već pokrajina i delova političih rukovodstava izvan Srbije (Hrvatska i BiH). Uspela je i da u savezno Predsedništvo kao jedan od predstavnika Srbije bude izabran Draža Marković, kao simbol borbe za promenu položaja Srbije i jedinstvo republike podeljene Ustavom iz 1974. Nova kriza je otvorena 1983, kada je na dnevnom redu bio izbor novog predsednika Predsedništva CK SKJ, koga je trebalo da predloži SK Srbije. Srbija je mogla da bira između Draže Markovića i Dobrivoja Vidića, dva svoja člana u tom telu. Predsedništvo CK SKS je 4. aprila 1983. izabralo Markovića. ${ }^{9}$

Otpori u Predsedništvu CK SKJ bili su znatni. Najveći Markovićev protivnik, Dušan Dragosavac iz Hrvatske, koristio je proceduralna pitanja da bi osporio predlog Srbije. Dušan Čkrebić je, kao predsednik CK SKS, pripremao izbor Markovića pojedinačnim razgovorima sa svim članovima Predsedništva CK SKJ, osim Dragosavca. Želeo je da time postigne ,blagovremeno otklanjanje eventualnih teškoća i problema oko predstojećeg izbora“. 10

O predlogu Srbije je odlučivala Kadrovska komisija Predsedništva CK SKJ 20. juna 1983. Nad Markovićevom kandidaturom je i dalje visila senka neizbora na prvoj sednici CK SKJ 1982. kada prilikom tajnog glasanja nije dobio dovoljan broj glasova za člana Predsedništva CK SKJ zbog akcije pokrajinskih delegata, kao i dela delegata iz Hrvatske i BiH protiv njega, što je izazvalo veliku

\footnotetext{
7 Петар Ристановић, Косовско питање 1974-1989 (Нови Сад: Прометеј, Београд: Информатика, 2019); Бојан Ђокић, „Српска јавност о међунационалним односима у Социјалистичкој аутономној покрајини Косово 1981-1989“, (докторска дисертација, Универзитет у Новом Саду, Филозофски факултет, Одељење за историју, 2019); Слободан Селинић, „Формирање албанске власти у Бујановцу - поглед уназад“, Нови стандард, 26. октобар 2020: https://www.standard.rs/2020/10/26/formiranje-albanske-vlasti-u-bujanovcu-pogled-unazad/.

${ }^{8}$ Bela knjiga - 1984. Obračun sa , kulturnom kontrarevolucijom" u SFRJ, priredili Kosta Nikolić, Srđan Cvetković i Đoko Tripković (Beograd: Službeni glasnik, 2010).

${ }^{9}$ AS, Đ-2, CK SKS, kutija 435, 1982-1984, Značajne informacije, Informacija sa 32. sednice P CK SKS; AS, Đ-2, CK SKS, kutija 414, 1983, Materijali sa 32. sednice Predsedništva CK SKS, održane 4. aprila 1983.

${ }^{10}$ Istorijski arhiv Beograda (IAB), fond Draže Markovića, k. 9, Dragoslav Draža Marković, Dnevničke beleške 1983. godine, str. 176; AJ, 507, SKJ, Predsedništvo CK SKJ, 39. sednica Predsedništva CK SKJ, 14. 6. 1983; IAB, fond Draže Markovića, k. 9, Dragoslav Draža Marković, Dnevničke beleške 1983. godine, str. 130.
} 
krizu koja je prevaziđena ponovljenim glasanjem i Markovićevim izborom. Posebno je bila uočljiva netrpeljivost prema njemu u SAP Vojvodini i među nekim političarima u BiH i Hrvatskoj. Skoro svi članovi (Dane Ćuić iz JNA, Dobroslav Ćulafić iz Crne Gore, Andrej Marinc iz Slovenije, Ilijaz Kurteši sa Kosova, Nikola Stojanović iz BiH, Mitja Ribičič iz Slovenije) iskazali su bojazan da posledice neizbora Markovića na prvom glasanju godinu ranije neće biti moguće izbeći na unutrašnjoj sceni i u reagovanjima iz inostranstva ako bude izabran za predsednika, ali su mu dali podršku, poštujući stav Srbije i ne želeći da dodatno slabe položaj zemlje u ionako složenim prilikama. Bilo je, međutim, ozbiljnih otpora i to iz severne pokrajine Srbije i BiH. Iz Vojvodine mu nisu opraštali borbu za republičko jedinstvo i otpore pokrajinskoj samostalnosti. ${ }^{11}$

Pitanje izbora predsednika Predsedništva CK SKJ rešeno je na sednici tog tela 30. juna 1983. Protivljenje Markoviću su u diskusiji otvoreno iskazala tri člana: Petar Matić iz SAP Vojvodine, Franjo Herljević iz BiH i Dušan Dragosavac iz Hrvatske. Kako većina članova nije bila voljna da stvara novu političku krizu, Marković je izabran za predsednika prećutno, bez glasanja, aklamacijom. ${ }^{12}$

Ozbiljno zaoštravanje političkih odnosa srpskog i hrvatskog vrha izazvalo je i pojavljivanje knjige Enigma Kopinič Venceslava Cenčića aprila 1983. u izdanju „Rada“. Srbija je i inače bila na udaru optužbi iz BiH i Hrvatske, ali i političara iz svojih pokrajina, zbog pisanja štampe i delovanja intelektualaca kritički nastrojenih prema sistemu. Knjiga je uzburkala duhove opisom stanja u KPJ i KP Hrvatske pre i tokom rata, Titovim moskovskim godinama, saradnjom sa NKVD-om itd. Da li je CK SKS bio nedovoljno politički „,budan“ ili je glavni urednik „Rada“ Branislav Milošević bio nedovoljno partijski poslušan? Politička šteta je mogla da proistekne već iz aluzija da se radilo o odgovoru na pojavljivanje knjige Dobrice Ćosića Stvarno i moguće u Rijeci, u kojoj su se, među člancima, ogledima, intervjuima i besedama, nalazili i njegova pristupna beseda u SANU i govor na sednici CK SKS 1968, bez partijskih odgovora i komentara, uprkos stava SK Srbije da takav materijal ne može da bude objavljen bez političkog komentara.

Knjiga Enigma Kopinič se nije pojavila iznenada. Javnost je obaveštena o najavi knjige u leto 1982. u intervjuu Radio Beograda sa Kopiničem i Cenčićem, čije su delove prenele Večernje novosti. Vlast je reagovala brzo. Predsedništvo CK SK Hrvatske je intervenisalo u srpskom rukovodstvu da se spreči objavljivanje knjige. Sprečeno je objavljivanje feljtona u štampi. ${ }^{13}$ Hrvatski i srpski centralni komiteti su, kako se Čkrebić izrazio, dugo bili u „dosta radnom

${ }^{11}$ AS, Đ-2, CK SKS, kutija 415, 1983, Materijali sa 39. sednice Predsedništva CK SKS, održane 29. juna 1983.

${ }^{12}$ IAB, fond Draže Markovića, k. 9, Dragoslav Draža Marković, Dnevničke beleške 1983. godine, str. 195, 196; AJ, 507, SKJ, Predsedništvo CK SKJ, 41. sednica, 30. 6. 1983.

${ }^{13}$ AJ, 507, SKJ, Predsedništvo CK SKJ, 36. zajednička sednica 10. maja 1983, Tekuća pitanja. 
kontaktu“. Još tokom jesenjih razgovora republičkih predstavnika u Zagrebu 1982. član Predsedništva CK SKH Josip Vrhovec je upozorio na taj tekst. Špiro Galović je reagovao tražeći od „Rada“ bolju ,verifikaciju“ rukopisa izborom recenzenta koji je trebalo da bude, ,isključivo za ratno vreme specijalista i koji ima ugled, nesporan ugled (...) u naučnom domenu a i u političkom životu“". Tako je izabran dr Pero Morača. ${ }^{14}$ Jedna od njegovih opštih zamerki odnosila se na autorov „subjektivizam“ u ,zastupanju“ Kopiniča. Morača je dao primedbe i na neke faktografske greške. Prema informacijama iz „Rada“ rukopis je 2. avgusta 1982. poslat i Vrhovcu na uvid, uz molbu da CK SKH dostavi svoje primedbe, ali odgovor nije stigao. ${ }^{15}$

Političke konsultacije su nastavljene 4. februara 1983. kada su Dušan Čkrebić, Špiro Galović i Radivoj Cvetičanin razgovarali sa urednikom „Rada“ Branislavom Miloševićem, koji je insistirao na što bržem objavljivanju knjige, očekujući da ona pomogne materijalnoj konsolidaciji preduzeća. Pri tome je rekao Čkrebiću da neke sugestije iz Moračine recenzije pisac nije hteo da usvoji (na primer, tvrdnju Morače da Kopinič nije bio Titov intimni prijatelj). Čkrebić je tražio da se objavljivanje rukopisa odloži bar do leta. Smatrao je da SK mora da ima uvid u dela koja govore o istoriji partije i Tita. Zahtev da knjiga ne izađe u tom trenutku pravdao je i time što je SKS već bio suočen sa nizom neprihvatljivih izdanja u publicistici i književnosti što je bilo „teško politički izdržati“, 16 dodajući da materijalni položaj preduzeća nije mogao da bude presudan za objavljivanje baš te knjige i tražeći od izdavača da nastavi saradnju sa Moračom. Čkrebićeva procena je bila da je Milošević bio nezadovoljan ishodom razgovora, zahtevom za odlaganje objavljivanja dela i potrebom dalje saradnje sa Moračom. Da se dve strane nisu razumele pokazalo se u aprilu 1983. kada je knjiga objavljena. Uvodni tekst je dao Leo Mates, a kao recenzenti su potpisani Veselin Đuretić i Pero Morača. Štampa je objavila intervjue sa Cenčićem i Kopiničem i delove knjige. Očekivano, time je nastao politički problem. ${ }^{17}$

Na zajedničkoj sednici Predsedništva CK SKJ i Predsedništva SFRJ 10. maja 1983. knjiga je i na osnovu ,letimičnog uvida“" osuđena kao „kontroverzna i neprihvatljiva“. Izneto je više zamerki. Negativno je vrednovano što je predstavljena kao biografija Kopiniča, a više se bavila drugim ličnostima, posebno Titom. Državnom vrhu je smetao utisak da je Kopinič odigrao presudnu ulogu u odbrani Tita od Kominterne i doveo ga na čelo KPJ. Na neodobravanje je naišla i tvrdnja da je Kopinič upozorio Rankovića, Kardelja i Lolu Ribara na delovanje Hebranga. Zasmetali su i davanje mogućnosti onima koji su došli u sukob sa partijom, poput Lea Matesa, da sude o onima koji su bili lojalni partiji kao i negativna zapažanja o ulozi Radeta Končara u pokušaju oslobađanja zatočenika

${ }^{14}$ AS, Đ-2, CK SKS, kutija 414, 1983, Materijali sa 36. sednice Predsedništva CK SKS, održane 9. juna 1983.

${ }^{15}$ AS, Đ-2, CK SKS, kutija 414, 1983, Materijali sa 36. sednice Predsedništva CK SKS, održane 9. juna 1983, Informacija o izdavanju knjige „Enigma Kopinič““.

${ }^{16}$ Među njima su bili Vunena vremena Gojka Đoga, Sudija i Nož Vuka Draškovića i druga dela.

17 Venceslav Cenčić, Enigma Kopinič (Beograd: Rad, 1983); AJ, 507, SKJ, Predsedništvo CK SKJ, 36. zajednička sednica 10. maja 1983, Tekuća pitanja. 
iz Kerestinca. Kritikovano je što je knjiga objavljena bez odobrenja Odbora za očuvanje i negovanje dela i imena Josipa Broza. Zahtevano je preduzimanje političke akcije protiv knjige, predlagano animiranje istoričara da je kritikuju i uticanje na javna glasila da kritički pišu o njoj i da je ne reklamiraju. ${ }^{18}$

Srpski i hrvatski političari su tokom sednice Predsedništva CK SKJ 8. juna 1983. razmenili mišljenja o knjizi. Josip Vrhovec je ukazao na mogućnost da njeno objavljivanje bude shvaćeno kao odgovor na pojavu Ćosićeve knjige u Hrvatskoj. Upozorio je da je u Hrvatskoj vladalo mišljenje da je ,greška načinjena u Srbiji i da bi to trebalo raščistiti“, a da je postojao utisak da „drugovi u Srbiji još nisu načisto“ kako je Ćosićeva knjiga mogla da bude objavljena i ,nije li to u Hrvatskoj neko nešto zabrljao“. Vrhovec je tražio krivičnu odgovornost zbog pojavljivanja knjige o Kopiniču, tvrdeći da je sadržala falsifikate, laži i klevete. Odgovorio je Draža Marković, podsećajući Vrhoveca da ni u Hrvatskoj nisu sprečavana hodočašća na kojima je učestvovalo 50.000 vernika i zaključio: „Ne može Centralni komitet Saveza komunista Srbije biti proglašen da odstupa od idejno-političke linije Saveza komunista Jugoslavije što nije u stanju da se izbori protiv nepovoljnog odnosa snaga u društvu sociologa (...) Ne može ni CK da pokrije svaki izdavački savet i svaki samoupravni organ“. ${ }^{19}$

Predsedništvo CK SKS je o objavljivanju knjige i nezadovoljstvu hrvatskog vrha raspravljalo 9. juna 1983. Odlučeno je da Predsedništvo CK SKS i Predsedništvo GK SKS Beograda formiraju radnu grupu koja će obaviti razgovor u IRO „Rad“. Najoštrija je bila Čkrebićeva reakcija. To je bilo očekivano od čoveka koji se morao osećati najodgovornijim što objavljivanje knjige nije sprečeno, ali i odgovornim pred rukovodstvom hrvatske partije. Zahtevao je disciplinske mere protiv Branislava Miloševića zbog ,pristrasnosti i nebudnosti, kao i davanja prevage materijalnoj koristi od ove knjige nad njenom idejno-političkom sadržinom“. Neminovno je postavljeno pitanje odnosa političkih rukovodstava jugoslovenskih republika prema delima nepoželjnim u nekoj drugoj republici. Čkrebić je podupirao takve odnose u kojima bi bilo sprečeno štampanje dela kome se protivi rukovodstvo druge republike „da nas ne bi kao političko rukovodstvo niko vukao za nos od strane tih izdavača“". Ivan Stambolić se slagao u tome da se o knjigama koje su političke poštuju stavovi CK republike na koju se odnose: „Ne može se ovde objaviti Kopinić ako ne može u Hrvatskoj, a bavi se političkim stvarima te republike i njene partije, njene istorije, kao što se ne može objaviti Dobrica Ćosić na Rijeci, zato što ne može da se objavi ovde, a bavi se najpolitičkijim pitanjima u Republici Srbiji“. I Stambolić je zahtevao da Branislav Milošević podnese konsekvence, ali je tražio da partija izbegne javno delovanje, da ne dozvoli da bude uvučena u javne rasprave o knjizi, ne želeći stvaranje ,nove dodatne političke afere“. Tako je razmišljao i Slobodan Milošević, predlažući da se akcija SK suzi ,maksimalno na pitanje postojanja dogovora i na pitanje nepoštovanja dogovora, čisto unutar partijsko pitanje discipline“" ${ }^{20}$

\footnotetext{
${ }_{18}$ AJ, 507, SKJ, Predsedništvo CK SKJ, 36. zajednička sednica 10. maja 1983, Tekuća pitanja.

${ }^{19}$ AJ, 507, SKJ, Predsedništvo CK SKJ, 38. sednica, 8. jun 1983.

${ }^{20}$ AS, Đ-2, CK SKS, kutija 414, 1983, Materijali sa 36. sednice Predsedništva CK SKS, održane 9. juna 1983.
} 
Iz vizure saveznog funkcionera i srpskog kadra, zaplet oko Cenčićeve knjige pratio je i Draža Marković. Pročitavši rukopis, zaključio je u avgustu 1982. da u njemu ima ,mnogo dokumenata, činjenica do sad nedovoljno poznatih javnosti““. Znao je da ,pred istorijom se ništa neće moći sakriti“, ali je uzimao u obzir i pritisak iz Hrvatske: „Pitanje je, međutim, da li je u ovom trenutku dobro i korisno objavljivanje jedne ovakve knjige“. Kada je knjiga izašla iz štampe, svestan da je njeno pojavljivanje izazvalo,,široko negodovanje od strane rukovodstva SR Hrvatske“, Draža Marković je zaključio da se knjiga „,morala štampati““. ${ }^{21}$

$$
* * *
$$

Povod za sledeći spor bio je neočekivan. Aleksandar Ranković, bivši potpredsednik SFRJ, koji je uklonjen sa funkcija na Brionskom plenumu 1966, umro je iznenada 19. avgusta 1983. u Dubrovniku, a sahranjen je tri dana kasnije u Beogradu. Uprkos zalaganjima vlasti da sahrana protekne u politički kontrolisanim tokovima, dve stvari su izmakle političkom nadzoru: masovnost i izrazi poštovanja Rankoviću tokom sahrane (aplauzi, skandiranje „Leka, Leka“, „Marko, Marko“, „Heroj Leka“, „Heroj Marko“, povici „Živeo“, a zvižduci i negodovanje kada je u govorima pominjana njegova osuda na Brionskom plenumu). ${ }^{22}$

Masovnost je bila prva pojava koja je bola oči vlastima i nije bilo spora da je prisustvo bilo masovno, ali je bilo mnogo odstupanja u proceni broja prisutnih. U Predsedništvu CK SKS 25. avgusta 1983. Slobodan Emreković je procenjivao broj prisutnih na 70 do 80 hiljada i govorio o „punom groblju“, „od kapele do groba“, Ivan Stambolić je preneo procenu Državne bezbednosti o čak 108.000 građana. Odudarala je procena Branka Pešića, koji je bio na sahrani. Koristio je poređenje sa „Zvezdinim“ stadionom koji je mogao da primi 90.000 ljudi, dodao da taj broj „ni na tri groblja ne može da stane“ i procenio broj okupljenih na maksimalno $50.000 .^{23}$ Savezni SUP je u informaciji od 2. septembra 1983. izvestio da je na sahrani bilo između 90.000 i 100.000 građana, među kojima dosta omladine, ali najviše onih srednje i starije dobi, veliki broj penzionisanih radnika organa unutrašnjih poslova, oficira i generala JNA, bivših rukovodilaca, lica sa odlikovanjima, domaćih i stranih novinara i snimatelja. ${ }^{24} \mathrm{Ma}-$ sovnost i političke poruke na sahrani Rankovića izazvale su veliku pažnju vlasti. Ta pažnja je multiplikovana unutarpartijskim sporovima oko odgovornosti za takav vid opozicionog delovanja.

${ }^{21}$ IAB, fond Draže Markovića, k. 9, Dragoslav Draža Marković, Dnevničke beleške 1983. godine, str. 156.

22 Бојан Димитријевић, Ранковић, други човек (Београд: Vukotić media, 2020); Branko Petranović, Istorija Jugoslavije 1918-1988 (Beograd: Nolit, 1988), III/383-388; Милан Пиљак, „Брионски пленум 1966. године. Покушај историографског тумачења догађаја“, Токови историје, бр. 1, (2010), 72-95; Љ. Димић, н. д.; IAB, fond Draže Markovića, k. 9, Dragoslav Draža Marković, Dnevničke beleške 1983. godine, str. 236; AS, Đ-2, CK SKS, kutija 415, 1983, Materijali sa 43. sednice Predsedništva CK SKS, održane 25. avgusta 1983.

${ }^{23}$ AS, Đ-2, CK SKS, kutija 415, 1983, Materijali sa 43. sednice Predsedništva CK SKS, održane 25. avgusta 1983 .

${ }^{24}$ Б. Димитријевић, н. д., 422; AJ, 507, SKJ, Predsedništvo CK SKJ, 46. sednica P CK SKJ, 15, 20. i 21. IX 1983, SSUP, Neke karakteristike aktuelne bezbedonosne situacije u zemlji, 9. septembar. 
Predsedništvo CK SKS je o dešavanjima na sahrani raspravljalo 25. avgusta 1983. Jedinstvo u oceni događaja nije bilo potpuno. Postojala je saglasnost oko karaktera - svi su se složili da je reč o političkoj demonstraciji (predsednik Predsedništva Srbije Nikola Ljubičić je upotrebio termin ,miting“) i da je prisustvo naroda bilo masovno. Međutim, predsednik Predsedništva CK SKJ Draža Marković je insistirao na tome da je ta demonstracija bila organizovana. To nije bio stav srpskog vrha, a posebno ne beogradskog, jer bi u tom slučaju politička odgovornost Gradskog komiteta na čelu sa Ivanom Stambolićem bila velika. Predsednik Predsedništva CK SKS Dušan Čkrebić i predsednik GK Beograda Ivan Stambolić su insistirali na tome da Državna bezbednost nije posedovala informacije o organizovanoj akciji niti da će građani na sahranu doći tako masovno (Stambolić je govorio o „spontanom okupljanju“ i da nije bilo nijednog indikatora organizovanosti). Oni su insistirali na tome da je specifičnost Beograda bila najveća koncentracija „dogmatskih snaga“, posebno pripadnika SUP-a penzionisanih posle pada Rankovića 1966. Čkrebić je pominjao i nacionalistički uticaj, ali još više „element Kosova“, to jest svest velikog broja ljudi da je na Kosovu bilo bolje stanje u vreme Rankovića. Konačno, smatrao je da je nezadovoljstvo iskazano na sahrani bilo i posledica složene ekonomske situacije. On i Stambolić su zaključili da je na sahrani bilo mnogo boraca iz revolucije i penzionisanih generala. Čkrebić i Dragoslav Marković su pozivali na dodatnu političku opreznost. Čkrebić je upozorio da treba voditi računa da se u budućnosti spreči ,mimohod“, „,neuobičajena poseta“ grobu, to jest da Rankovićev grob ne postane simbol protivnika režima. Čkrebić je bio otvoreniji od ostalih u tumačenju značaja događaja na sahrani, shvatajući da su oni bili pokazatelj velikog nezadovoljstva u društvu, s kojim je SK morao da računa: „da znamo brate i da mi ne živimo u nekim oblacima da znamo da budemo realni da šta imamo i s čim treba realno da računamo“. ${ }^{25}$

Predsedništvo CK SKJ je više puta razmatralo politički aspekt sahrane Rankovića (6. septembra, 4. i 14. oktobra, 22. novembra). Osnovni ton diskusije bile su optužbe iz pokrajina i Hrvatske i BiH upućene Savezu komunista Srbije i beogradskoj partijskoj organizaciji i vlastima zbog srpskog nacionalizma. Pokrajinski političari (Slavko Veselinov, Petar Matić) i pojedini političari iz Hrvatske i BiH (Dušan Dragosavac, Jure Bilić, Branko Mikulić, Hamdija Pozderac, Nikola Stojanović) koristili su i inače svaku priliku da u saveznom partijskom predsedništvu napadnu rukovodstvo Srbije zbog pisanja štampe u Srbiji ili delovanja intelektualaca koje je bilo suprotno politici vlasti, da pokušavaju da se mešaju u rad Saveza komunista Srbije, predlažu ili zahtevaju zabranu pojedinih knjiga i šire strah od srpskog nacionalizma, a masovan dolazak građana na sahranu Aleksandra Rankovića bio je samo jedan od povoda za takve napade. ${ }^{26}$

${ }^{25}$ AS, Đ-2, CK SKS, kutija 415, 1983, Materijali sa 43. sednice Predsedništva CK SKS, održane 25. avgusta 1983 .

${ }^{26}$ Učesnik rasprava u saveznom partijskom predsedništvu Dušan Čkrebić je ocenio da je srpsko rukovodstvo „na vratu (...) kao kritičare imalo“ sve druge osim političara iz Crne Gore i delimično Slovenije, za koje je rekao da su bili „malo uzdržani polazeći od civilizacijskog odnosa prema svačijoj smrti“, dok su „članovi Predsedništva iz Hrvatske, BiH, Vojvodine i Kosmeta 
Predsedništvo CK SKJ je 6. septembra 1983. razmatralo informacije o sahrani kojima je raspolagalo. Zauzimanje stavova je odloženo za sledeću sednicu. Telo sastavljeno od predstavnika šest republičkih, dve pokrajinske i jedne armijske partijske organizacije bilo je i po ovom pitanju poligon za iznošenje pogleda iz vizure partikularnih interesa. U tom smislu je odbačena Informacija koju je ovim povodom poslalo Predsedništvo SFRJ, a koju je 31. avgusta sastavila Služba Predsedništva SFRJ za pitanja zaštite ustavnog poretka. Taj tekst je bez uvijanja identifikovao najvažnije uzroke nezadovoljstva građana, ispoljenog između ostalog i na sahrani Rankovića. Povodom masovnosti na sahrani, u prvi plan je istaknuta zabrinutost zbog prisustva velikog broja mladih ljudi i penzionisanih generala i oficira JNA, posebno što je dolazak bio spontan. Ponašanje „izvesnog“ broja građana je ocenjeno kao ,izraz masovnog protesta, odnosno nezadovoljstva situacijom $u$ društvu u celini, a posebno njihovim položajem $-u$ prvom redu ekonomskim i političkim - u okviru našeg društva“. Za najvažnije uzroke nezadovoljstva su ocenjeni visoka inflacija, koja je ugrožavala čak i standard radnika sa srednjim prihodima, činjenica da je do povećanja cena dolazilo posle usvajanja Programa stabilizacije i dramatičnog istupanja Milke Planinc, osećanje nemoći mladih ljudi da takvo stanje menjaju preko političkih i društvenih organizacija, visoka stopa nezaposlenosti i nezadovoljstvo stanjem na Kosovu. U Informaciji je stajala sledeća ocena: „Radni ljudi su nezadovoljni i posebno zabrinuti zbog faktičkog političkog nejedinstva u društvu u nekim kapitalnim pitanjima i neodgovornosti u društvu, počev od OOUR i najužih društveno-političkih zajednica do najsloženijih OOUR i najviših društvenih i društveno-političkih organa u pokrajinama, republikama i federaciji“. Zatim: "Očigledno je da ovde nije reč o neprijateljskim istupima nego o zabrinutosti radnih ljudi za budućnost zemlje“. Pomenuto je i nezadovoljstvo „radnih ljudi“ nagrađivanjem i beneficijama zaposlenih u neproizvodnim delatnostima. Kao uzrok nezadovoljstva u narodu pomenuta je nedoslednost u izricanju kazni separatistima na Kosovu i muslimanskim nacionalistima u Sarajevu (izricanje drastičnih kazni, pa kasnije smanjivanje ili obrnuto). Pomenuto je jačanje nacionalizma, pri čemu je detaljno opisan incident kod Sjenice kada je 2. avgusta grupa muslimanskih mladića „bezrazložno“ napala grupu mladića i devojaka Srba. ${ }^{27}$

Partijskom vrhu, međutim, bilo je lakše da okrivi starog neprijatelja, pre svega srpski nacionalizam, nego da uzroke krize potraži u posledicama svoje višegodišnje politike, na koje je Informacija Predsedništva SFRJ jasno ukazivala. Informaciju je posebno osudio Hamdija Pozderac $(\mathrm{BiH})$, podržan od Ilijaza Kurtešija (SAP Kosovo), ali su je se odrekli i Čkrebić i Draža Marković. Bosanskohercegovački političari su bili sasvim uobičajili da se mešaju u događaje u Srbiji,

bili agresivni i netolerantni“. Душан Чкребић, Између памћења и заборава. Мемоарски и политички есеји (Нови Сад: Прометеј, 2007), 531; M. Đekić, n. d., 296, 297.

27 „Kada su se mladići srpske nacionalnosti razbežali, mladići muslimanske nacionalnosti jurili su za njima (i na konju), kojom prilikom su ispalili i nekoliko hitaca iz pištolja“, a one Srbe koje su uhvatili su ,uz pretnju pištolja tukli, maltretirali i psovali im srpsku majku“. AJ, fond 803, Predsedništvo SFRJ, Savezni savet za zaštitu ustavnog poretka, 1790, 19. septembar 1983, Strogo poverljivo, Zapažanja i ocene o nekim aktuelnim pojavama... 
daju ocene stanja u medijima i u kulturi, arbitriraju u odnosima između republike i pokrajina, uvek na strani pokrajina, ali su se osetili veoma pogođenim čim su kao uzrok nezadovoljstva građana pomenuti i događaji u BiH. Slično su reagovali i pokrajinski političari sa Kosova. Pozderac i Kurteši su bili nezadovoljni što su u Informaciji Predsedništva SFRJ o uzrocima nezadovoljstva građana pominjani i događaji u njihovim sredinama (nedoslednost $\mathrm{u}$ izricanju kazni muslimanskim nacionalistima u Sarajevu i albanskim nacionalistima u Prištini). Pozderac je tvrdio da stavovi izneti u Informaciji ,ne idu u prilog dobrim odnosima između republika odnosno između nas u političkim strukturama“. I Dane Ćuić je Informaciju posmatrao iz ugla interesa partije koju je zastupao (SK JNA), pa mu je smetalo isticanje prisustva velikog broja penzionisanih oficira. Epilog je bio odbacivanje Informacije koja je poslata od Predsedništva SFRJ. Tačnije, Predsedništvo CK SKJ je odlučilo da se prema njoj odnosi kao da je nema. Umesto suočavanja sa lošim posledicama državne politike, Predsedništvo CK SKJ se okrenulo napadima na „srpski nacionalizam“, „,entralističke snage“ i Gradski komitet Beograda, kao „,krivce“ za dolazak velikog broja građana na sahranu Rankoviću i politički nepodobne pojave na sahrani. Masovnost na sahrani davala je odličnu priliku za napade na SKS zbog srpskog nacionalizma. Franjo Herljević je zaključio da je reč o demonstraciji ,o kojoj se mi trebamo zamisliti““ i da su na sahrani prevladale nacionalističke, dogmatske, centralističke snage, ,jedan veliki broj šljama“. Jure Bilić (Hrvatska) iznosio je zamerke na intervju sa profesorom Simom Ćirkovićem o doseljavanju Slovena na Balkan koji ,ima jedan prizvuk oko položaja Srbije kroz istoriju do današnjeg dana" i na pisanje Politike o atentatu na kralja Aleksandra. Zaključio je: „Te istorijske teme kako se komponiraju, uvijek ima jedan prizvuk, ili smo mi već toliko osjetljivi i toliko, vidimo svugdje pakosti, a ima gdje ih nema, ali bilo bi dobro da se sve to vidi“" i tražio od predsednika CK SKS Čkrebića da se angažuje po tom pitanju. Petar Matić, jedan od najradikalnijih zastupnika samostalnosti pokrajina i dosledni protivnik politike rukovodstva Srbije koja je imala za cilj uspostavljanje jedinstva republike, već na ovoj sednici uveo je u priču temu koja će se ispostaviti kao najspornija narednih sedmica odgovornost Gradskog komiteta Beograda. Čak je tražio da na iduću sednicu Predsedništvo CK SKJ pozove i predsednika GK Ivana Stambolića „da on nama kaže i direktno i izvorno o tome kako oni vide situaciju i da objasni zašto je to takva situacija“. Zahtevao je odgovornost za one „koji su odgovorni za situaciju (...) morali bi drugovi iz Gradskog komiteta da kažu, da objasne“. Matićeva ideja da se izvrši svojevrsno partijsko saslušanje Ivana Stambolića nije dobila podršku. Andrej Marinc (Slovenija) smatrao je da je u SKS trebalo održati raspravu o događajima na sahrani, ali je odbacio pozivanje Stambolića u Predsedništvo. Nikola Stojanović (BiH) označio je masovnost na sahrani za ,demonstraciju raznorodnih antisamoupravnih i antisocijalističkih snaga“" ${ }^{28}$

Kao predsednik GK SKS Beograda Ivan Stambolić je imao sasvim drugačije tumačenje uzroka velikog okupljanja građana na sahrani nego političari iz

\footnotetext{
${ }^{28}$ AJ, 507, SKJ, Predsedništvo CK SKJ, 45. sednica P CK SKJ, 6. 9. 1983.
} 
srpskih pokrajina i drugih republika u saveznom rukovodstvu SK. O tome je dugo govorio na sednici Predsedništva CK SKS 8. septembra 1983. Smatrao je da metodi Državne bezbednosti korišćeni za kontrolu grupa i pojedinaca označenih kao politički neprijatelji nisu mogli biti efikasni u predviđanju nezadovoljstva običnih građana izazvanog lošim stanjem u državi. ${ }^{29}$ Stambolić i GK SKS Beograda su insistirali da su masovno okupljanje, aplauzi i klicanje Rankoviću na sahrani predstavljali ,izuzetno višeznačno politički događaj“, koji ,prevazilazi i nadilazi Beograd“. Stambolić je time skidao odgovornost za takvu opozicionu demonstraciju sa beogradske partije i vlasti, insistirajući na specifičnostima Beograda kao najvećeg i glavnog grada i na ukupnoj krizi društva kao okidaču za takvo nezadovoljstvo. Analize beogradske vlasti su pokazivale da je u gradu postojao veliki broj stanovnika koji su ili bili neprijateljski orijentisani ili su mogli biti nezadovoljni stanjem u državi. ${ }^{30}$ Ključno pitanje za njega je bilo kako se desilo da toliko mnogo ljudi oda poslednju počast nekome ko je označen kao državni neprijatelj, a da među njima ne budu ni ,pročetnički elementi“, ni „ostaci buržoazije ili predratnih i neprijateljskih struktura“, a da čak ni ibeovci nisu došli u velikom broju. Ivan Stambolić je prisutne opisao kao ,složenu, višeslojnu, različitu po motivima“ masu. Smatrao je da je veliki broj bivših boraca došao na sahranu iz pijeteta prema Rankoviću, pri čemu je među borcima i inače tinjalo nezadovoljstvo zbog protokolarnih propusta prilikom proslava na kojima su narodni heroji smeštani u treći red, a aktuelni političari na počasna mesta. ${ }^{31}$

${ }^{29}$ Preneo je obaveštajne i političke ocene sa gradskog nivoa da je događaj ,iznenadio političke radnike, političke strukture, iznenadio Savez komunista i njegovo rukovodstvo, ali je iznenadio čak i Službu državne bezbednosti“. Stambolić je zaključio da je stanje u zemlji bilo takvo „da se manje nego ikad smemo oslanjati samo na informacije Službe državne bezbednosti“, jer su njeni metodi i sistem rada ,potpuno zakazali“ i jer je Državna bezbednost bila suočena sa ,nekim novim fenomenima, novim načinom ispoljavanja, možda stihijskim, spontanim, koji se teže predviđa i sagledava, jer u njemu nisu eksponirane snage i nosioci neprijateljske delatnosti“. AS, Đ-2, CK SKS, kutija 416, 1983, Materijali sa 45. sednice Predsedništva CK SKS, održane 8. septembra 1983.

${ }^{30}$ Stambolić je pokušavao da sa Beograda skine optužbe za krivicu zbog masovnosti Rankovićeve sahrane podsećanjem da je u milionskom gradu bilo 9.000 ljudi kojima je suđeno za dela protiv naroda i države, 1.000 učesnika četničkog pokreta, oko 3.500 ibeovaca, veliki broj onih kojima je suđeno zbog nasilja, diverzija i špijunaže, 7.000 pristalica IB-a kojima nije suđeno, na hiljade povratnika iz istočnoevropskih ili zapadnoevropskih zemalja i članova porodica emigranata, 750 stalno nastanjenih stranaca, 1.000 stranaca sa jugoslovenskim državljanstvom, 3.000 studenata iz arapskih zemalja, 200 stranih diplomatskih predstavništava, desetine dopisništava stranih agencija i novina i stranih kulturno-informativnih centara, oko 200.000 građana koje je kao svoje vernike okupljala Srpska pravoslavna crkva, 25.000 katolička, 50.000-70.000 Islamska verska zajednica, 20.000 doseljenika sa Kosova, 3.000 penzionisanih radnika SUP-a, 160.000 penzionera, 106.000 boraca, 35.000 penzionisanih pripadnika službi oružanih snaga, veliki broj političara koji su se razišli sa SK, oko 70.000 nezaposlenih i 100.000 studenata. Isto.

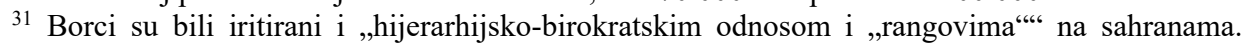
„Ako je u trenutku smrti u penziji, čovek sa ne znam kako sjajnom, blistavom revolucionarnom biografijom, ima drugačiji tretman od nekog ko ima sasvim drukčiju, skromniju biografiju, odnosno manje zasluge za tu revoluciju, ali se u trenutku smrti nalazi na nekoj funkciji. Takve razlike - pa još ako je kojim slučajem sahrana istog dana - kod boraca izaziva veliko nezadovoljstvo“, naveo je Stambolić. Isto. 
Stambolić je, ipak, ključan razlog za masovnost video u nezadovoljstvu stanjem u državi. „Aplauz na sahrani sigurno je i aplauz jednom dogmatskom vremenu ili rankovićevski shvaćenoj monolitnosti i jedinstvu, redu, poretku i slično (...) kad bismo išli da vršimo anketu i pitali na primer - ,šta misliš, ko je bio Ranković“" - od trojice dvojica bi odgovorila - ,radi se o čoveku koji je važio za čoveka reda, poretka, jedinstva, bezbednosti““‘. Stambolić je otvoreno govorio o brojnim propustima partijskog i državnog vrha i opominjao da će ubuduće eskalacija nezadovoljstva možda biti još izraženija. Ton njegove kritike državne politike i rukovodilaca bio je veoma oštar. Skretao je pažnju na stalnu iznenađenost i nespremnost rukovodstva zemlje na velike krize, prebacujući mu da stalno „šokira ljude“. Predsednik GK SK Beograda je govorio i o stalnim političkim sukobima unutar vlasti, napadima sa vrha države na gradsku vlast zbog uvođenja bonova za snabdevanje, nedorečenosti u politici cena (,Savezni funkcioneri su krenuli sa hajkom da hleb ne može da poskupi više od $16 \%$, da bi oni sami posle pomerili na 18 , pa na 22 , da bi se zaustavili na $29 \%$ “), nemogućnosti da se običnim ljudima objasni da država i uvozi i izvozi pšenicu. ${ }^{32}$ To je za njega bio nastavak opozicionih delovanja u publicistici, književnosti, humoru, pozorištu: „,Ta se granica stalno pomera, milimetar po milimetar, tačku po tačku (...) A na idućem takvom skupu ili sličnom skupu od sto ili više hiljada ljudi, nisam siguran da unutar neće biti postavljeno i dinamitno jezgro koje će ih pozvati na Trg Marksa i Engelsa, da pođu ulicama... Svi znamo šta bismo u takvoj situaciji morali da činimo - da ih sačekamo, da ih tučemo“. Gradski komitet Beograda je davao masovnom prisustvu građana na sahrani Rankovića mnogo širi značaj i uzroke tražio pre svega u nezadovoljstvu običnih ljudi krizom u zemlji, svestan oštrine socijalnog raslojavanja, kojim je pad standarda najviše pogađao radništvo i penzionere sa niskim penzijama u velikim gradovima koji nisu imali „nikakvo zaleđe u unutrašnjosti““. O tome svedoči i to što je u gradu pokrenuta „mobilizacija svih političkih aktiva“ kako bi se u organizacijama udruženog rada u razgovorima sa radnicima i komunistima pronalazila rešenja za porodice koje su bile ugrožene padom standarda $i$ skokom cena. Međutim, reči „neka drugovi rukovodioci vrate svoje pare sa svojih računa u inostranstvu“, koje su se mogle čuti na sastancima u opštinskim komitetima, ukazivale su na dubinu nezadovoljstva građana i stepen gubitka poverenja $u$ vlast i partiju. $^{33}$

Na toj sednici Predsedništva CK SKS, 8. septembra 1983, Nikola Ljubičić se složio sa ocenama Ivana Stambolića da je osnovni razlog te ,tihe demon-

32 „Prosečna svest, ja moram da kažem i moja svest, teško može da shvati da zemlja sa jedinstvenim tržištem, jedinstvenom valutom (...) tako bar u Ustavu piše, istovremeno izvozi i uvozi pšenicu, s time što je izvozi jeftinije od uvoza! Ne može to da shvati radnik - građanin, pa makar mi dubili na glavi“. Isto.

33 „Nema više sitnih i sporednih stvari i pitanja. Više se ne zna (...) koje pitanje može biti povod za eskalaciju raznoraznih istupa i nastupa ili okupljanje građana sa teško predvidivim potencijama i ishodima (...) U nekoj drugoj prilici skupiće nam se 300 hiljada ljudi (...) Na Novom groblju je učinjen krupan korak dalje u osvajanju nečega što se očituje u tome da hiljade ljudi slobodno može da skandira „Leka“, „Marko“, da aplaudira, da oni koji su se tu skupili vrše pokušaj rehabilitacije Aleksandra Rankovića i njegove politike“. Isto. 
stracije“ nezadovoljstvo stanjem u zemlji i „rukovodećim ekipama“ čemu su štampa i televizija mnogo doprineli iznoseći u javnost sve probleme društva i time „devalvirali ulogu našeg rukovodećeg sastava“. „Opasno je ako mi devalviramo i stvorimo bezlična rukovodstva i bezlične rukovodioce. To će biti opasno po ovo društvo, vi ste mladi povedite o tome računa (...) koji su to sada autoriteti u narodu kome ovaj narod može verovati, još veruju Savezu komunista u cjelini, organizaciji, ali pojedincima, koji su to pojedinci, nađite mi ih da vidimo“. Republički sekretar za unutrašnje poslove Svetomir Lalović je tvrdio da bezbedonosni organi nisu imali nikakva saznanja o pripremama organizovane masovne sahrane ,iako imamo vrlo razvijen operativni rad i praćenje svih struktura neprijatelja, posebno u Beogradu“. Podsekretar u Republičkom sekretarijatu za unutrašnje poslove Obren Đorđević je potvrdio da Služba bezbednosti, prateći više hiljada lica označenih kao neprijatelje, nije primetila nikakve pripreme za masovan dolazak građana na sahranu (,o organizovanju nema govora“). Da bi otkrila strukturu posetilaca policija je više puta gledala film sa sahrane, ,preslišavala“ svoje operativce prisutne na sahrani i zaključila da je najviše bilo ,sredovečnih građana“. 34

Ivan Stambolić je na sednici Gradskog komiteta 21. septembra 1983. uspeo da nametne svoje gledište o ukupnoj krizi u društvu kao pokretaču nezadovoljstva iskazanog na sahrani, ali se čuo i disonantni ton Rodoljuba Stanića, koji je kritikovao način na koji je Stambolić shvatao politiku i rukovođenje gradom. Zamerio je prvom čoveku beogradskih komunista da u govoru punom optužbi na račun rukovodstva zemlje nije bio samokritičan. ${ }^{35}$

Nesporazumi političkih struktura su zaoštreni kada je Predsedništvo CK SKJ 4. oktobra usvojilo Informaciju (koja je datirana 5. oktobrom) povodom smrti i sahrane Rankovića. U Informaciji je stajalo da se radilo o očitom političkom neslaganju sa ,principijelnim ocenama“ SKJ o ,delovanju i političkoj poziciji“" Rankovića. Povod za političko neslaganje saveznog partijskog predsedništva, sa jedne, i GK Beograda i SKS, sa druge strane, bilo je nekoliko ocena u Informaciji. Najpre, navedeno je da su sahranu iskoristili ljudi sa ,velikosrpskom nacionalističkom i birokratsko-etatističkom orijentacijom" za ispoljavanje svojih stavova. Drugo, povučena je paralela sa događajima na Kosovu 1981. Na kraju, najvažniji je bio poslednji pasus, koji je predstavljao otvorenu političku osudu Gradskog komiteta Beograda, na čelu sa Ivanom Stambolićem: „Redovnom kritičkom analizom stanja i kretanja u svakoj sredini, ovakvi i slični slučajevi moraju se unapred uočiti i uvek, konkretnim političkim akcijama, na vreme sprečiti. Povodom sahrane A. Rankovića posebne pouke i upozorenja treba da izvuku Savez komunista i rukovodstvo grada Beograda“" ${ }^{36}$

Ova informacija je sačinjena kao rezultat rasprave na Predsedništvu CK SKJ 4. oktobra 1983. Sporni pasus nije bio u predlogu Informacije, ali jeste dodat posle diskusije. Najviše napada na GK Beograda i SK Srbije dolazilo je od pokra-

\footnotetext{
${ }^{34}$ AS, Đ-2, CK SKS, kutija 416, 1983, Materijali sa 45. sednice Predsedništva CK SKS, održane 8. septembra 1983.

${ }^{35}$ IAB, fond 865, Gradski komitet, 45, 1983, 21. 9. 1983.

${ }^{36}$ IAB, 865, Gradski komitet, 45, 1983, 24. 10. 1983, Strogo pov. 02-86; D. Jović, n. d., 334.
} 
jinskih političara iz Vojvodine (Slavko Veselinov i Petar Matić) i Hrvatske (Dušan Dragosavac). Masovnost na sahrani je bila povod za novi napad na Srbiju sa optužbom za nedovoljnu borbu protiv nacionalizma. Slavko Veselinov nije želeo da slučaj prođe bez ukazivanja na političku odgovornost Gradskog komiteta (,da se vidi i politička odgovornost", ,to nije hiljadu ljudi na jednoj sahrani, to je sto hiljada ljudi sa određenim kazivanjem, skandiranjem (...) teško je to prihvatiti u političkoj oceni da 200 hiljada komunista Beograda ne zna da li će se na jednom mestu u Beogradu skupiti tog dana 100 hiljada ljudi“"). Zahtevao je i uvid u poslate telegrame saučešća, tvrdeći da nisu slati bez ,političkog razloga i interesa“. Petar Matić je odgovornost proširivao na celu partiju, pre svega na SKS, zahtevajući da se postave zadaci ,ne samo Savezu komunista Srbije ili Gradskom komitetu i svim drugim delovima Saveza komunista oko mera koje treba preduzeti da se tako nešto, bez posledica po onog ko odgovara za političko stanje i odnose ne može i ne sme desiti“. Smatrao je da analiza koja je vršena u saveznom Predsedništvu neće biti dovoljna ,pouka“" za SKS i GK. Dušan Dragosavac je potencirao odgovornost beogradskog rukovodstva rečima: „oni nisu tamo vlasnici-feudalci, oni samo imaju pojačanu odgovornost prema svima“. Dodao je da su događaji u Beogradu imali odraza na stanje u celoj zemlji, tražio analizu političkog stanja u Beogradu i njegovu promenu. ${ }^{37}$

Ovom informacijom je ocena događaja na sahrani Rankovića dobila novu dimenziju -unutarpartijsko razračunavanje i novo nametanje Srbiji hipoteke srpskog nacionalizma. Ovako intoniran poslednji pasus imao je određene političke implikacije, posebno u tadašnjoj političkoj praksi u kojoj je uvođenjem jednogodišnjeg mandata, uz jedan reizbor, svaka godina bila izborna. S obzirom na komplikovanu i dugu proceduru izbora i reizbora, izborni proces je trajao mesecima. Pošto bi u proleće (obično april ili maj) bili izabrani funkcioneri, već na jesen je trebalo otpočeti novi izborni postupak koji bi bio okončan sledećeg proleća. U leto 1983. Ivanu Stamboliću je bila druga godina mandata predsednika GK, a on je već bio viđen za predsednika CK SKS na podeli funkcija idućeg proleća. Slično je bilo i sa drugim funkcionerima u Gradskom komitetu, koje je očekivao novi ciklus političkog ,uhlebljenja“, to jest podele funkcija. U takvoj situaciji kritike iz Predsedništva CK SKJ na račun Gradskog komiteta mogle su da ostave negativne političke posledice po gradske partijske funkcionere, tim pre što je savezni vrh odlučio da se Informacija predoči partijskom članstvu u zemlji do nivoa opštinskih komiteta. Istovremeno, Gradski komitet Beograda nije bio bilo koja lokalna partijska organizacija. Opravdano je reći da je SKJ bio sačinjen od osam partija, ali i da je postojala i deveta (organizacija SK u JNA). U tom smislu je Gradski komitet Beograda bio sledeći u hijerarhiji, a njegov uticaj je posebno bio izražen u Srbiji.

Savezna informacija je dostavljena svim republičkim i pokrajinskim partijskim organizacijama u zemlji, koje su trebale da ih proslede opštinskim komitetima, ali su GK SKS Beograda i Predsedništvo CK SKS zadržali Infor-

\footnotetext{
${ }^{37}$ AJ, 507, SKJ, Predsedništvo CK SKJ, 47. sednica P CK SKJ, 4. 10. 1983.
} 
maciju i nisu je prosledili lokalnim organizacijama nezadovoljni poslednjim pasusom uperenim protiv beogradskog komiteta i vlasti. Predsednik GK Beograda Ivan Stambolić iskazao je predsedniku CK SKS Dušanu Čkrebiću telefonom nezadovoljstvo sadržajem Informacije i skrenuo pažnju da poslednji stav nosi opasnost da ga komunisti shvate kao pozivanje na odgovornost gradskog rukovodstva, što bi dovelo u pitanje njegovu stabilnost. ${ }^{38}$

Dušan Čkrebić je primedbe GK izneo na sednici Predsedništva CK SKJ 14. oktobra. Potencirao je veliko nezadovoljstvo u Beogradu. Kritikovao je zahtev da se spreče slični slučajevi („osim kod neke nove pretpostavke da zatvorimo groblje i da milicijom razjurimo ljude“"). Preneo je da je zahtev da rukovodstvo beogradske organizacije izvuče pouke shvaćen u Beogradu kao poziv za smenu rukovodstva. U diskusiji je potvrđeno da je taj pasus dopisan posle sednice. Zaključeno je da se on izostavi, a pošto je Informacija već upućena da se izmena unese u zapisnik i da se on briše samo za članstvo u Beogradu. Posebno je Nikola Stojanović zastupao tvrd stav, najpre odbijajući primedbe na Informaciju, a potom odbijajući predlog Kire Hadži Vasileva da se pokrajinski i republički komiteti obaveste da je pasus greškom unet. ${ }^{39}$

Predsedništvo CK SKJ je dostavilo novu informaciju bez spornog pasusa, pa je tako članstvo SKJ bilo podeljeno na one u centralnoj Srbiji, koje je trebalo upoznati sa novom informacijom u kojoj nije bilo optužbi na račun beogradske organizacije i komuniste u drugim delovima zemlje kojima je predočena prva informacija. Ovakav rasplet je za Gradski komitet i Ivana Stambolića i dalje bio nepovoljan. Time nije skinuta odgovornost sa Gradskog komiteta pred svim komunistima, već samo pred onima u gradu. Stambolić je ponovo saopštio Čkrebiću neslaganje sa polovičnim rešenjem. ${ }^{40}$

Stavovi su i dalje bili nepomirljivi. To se videlo iz diskusije u Predsedništvu GK 17. oktobra 1983, koju je Ivan Stambolić sumirao na sednici Predsedništva CK SKS 19. oktobra 1983. Težište je stavio na opšte nezadovoljstvo u narodu stanjem u zemlji kao osnovnim motivom za nezadovoljstvo iskazano na sahrani Rankovića, potencirajući ekonomsku krizu, pad standarda, stagniranje proizvodnje, pad plata, nejedinstvo rukovodstva zemlje i političko raspoloženje u Beogradu koje je karakterisala zabrinutost među borcima, radnicima i omladinom. Političku situaciju u Beogradu je ocenio veoma nepovoljnom, a razlog za to je tražio u neuspehu državne politike. Potencirao je „kontrarevoluciju“ i stanje na Kosovu, pomenuvši neke od razloga za nezadovoljstvo u narodu - partijsko nekažnjavanje Bakalija, a traženje da se iz SK isključe oni koji se iseljavaju sa Kosova, činjenica da je Mahmut Bakali isteran iz partije kao krivolovac, a ne zbog politike koja je

${ }^{38}$ IAB, 865, Gradski komitet, 45, 1983, 24. 10. 1983, Strogo poverljivo, Neautorizovane magnetofonske beleške, sa dela 36. sednice Predsedništva GK Organizacije SK u Beogradu održane 17. oktobra 1983.

${ }^{39}$ AJ, 507, SKJ, Predsedništvo CK SKJ, 41. sednica, 30. 6. 1983; IAB, 865, Gradski komitet, 45, 1983, 24. 10. 1983, Strogo pov. 1/27.

${ }^{40}$ IAB, 865, Gradski komitet, 45, 1983, 24. 10. 1983, Strogo poverljivo, Neautorizovane magnetofonske beleške, sa dela 36. sednice Predsedništva GK Organizacije SK u Beogradu održane 17. oktobra 1983. 
dovela do pobune 1981, ,trpanje u isti koš“ ekonomskih uzroka iseljavanja i nacionalističkih pritisaka na Srbe itd. Smatrao je da su uzroci pobune na Kosovu bili najpre u samoj pokrajini, pa u Srbiji i u Jugoslaviji, dok je redosled izvora uzroka za nezadovoljstvo na sahrani bio obrnut. Kritikovao je što su pominjane samo „,srpsko-nacionalističke“ i ,,birokratsko-centralističke“" snage, a ne i drugi „,neprijatelji“ (građansko-liberalistički, iredentistički, separatistički, anarho i ultra levi, ibeovski). Kada je rekao da pre ekonomske krize i događaja na Kosovu prisustvo na sahrani ne bi bilo masovno, izrekao je kritiku na račun rukovodstva države zbog stanja u zemlji. Pojačao ju je novim podsećanjem da je narodu na noćnoj sednici Skupštine SFRJ saopšteno da je dovedena u pitanje sudbina zemlje, da je ista dramatična poruka poslata i posle albanskog nasilja na Kosovu, a da su u oba slučaja rukovodioci prećutali svoju odgovornost. U događajima na sahrani je video mnogo dublju poruku naroda od odavanja pošte Rankoviću. ${ }^{41}$

Gradski komitet Beograda je na sednici 24. oktobra 1983. ponovo odbacio kritiku i odgovornost za političku demonstraciju protivnika vlasti. Zahtevano je da poslednji pasus bude izostavljen i iz Informacije poslate svim partijskim organizacijama u zemlji, a ne samo u Beogradu, da budu navedeni razlozi izostavljanja i da bude bliže objašnjeno dovođenje u vezu događaja na sahrani i zbivanja na Kosovu. ${ }^{42}$ Iz uvodnog izlaganja člana Predsedništva GK Miloša Stanimirovića je bio uočljiv strah gradskog partijskog rukovodstva od političkih posledica kritika iz saveznog vrha - ukazao je da je Informacija poslata u predizbornim mesecima kada je ocenjivan rad svakog rukovodioca i da bi poslednji pasus Informacije mogao $\mathrm{u}$ drugim delovima zemlje umanjiti poverenje u partijsko rukovodstvo glavnog grada. Ponovio je stav gradskih vlasti da je glavni uzrok iskazivanja nezadovoljstva bilo ukupno ekonomsko i političko stanje u zemlji, za šta odgovornost nije trebalo konkretizovati na Beograd, već rasporediti srazmerno stvarnom uticaju i odgovornosti u državi. Ukazao je na neprihvatljivost delova iz savezne Informacije iz kojih je sledio zaključak da je Beograd u Jugoslaviji središte srpskog nacionalizma i centar unitarističkocentralističkih snaga. Suprotno tome, insistirao je na specifičnosti glavnog grada, kao najmnogoljudnijeg, kao stecišta raznih ideja i ideologija, na koji se reflektovala većina događaja u zemlji, a „,danas naročito nepotučena kontrarevolucija na Kosovu“. 43

41 „Na groblju se čuo aplauz čoveku koji je druge pozivao na odgovornost, a koji je sam, uglavnom korektno, poneo svoju odgovornost za sopstvene greške, svoje koncepcije i politiku. Ali, nije li možda taj aplauz ravan zvižduku jednom metodu koji se kod nas uvrežio, prema kome su za sve greške krivi svi, a konkretno niko, naročito u rukovodstvu (...) U aplauzima na groblju možda bi trebalo čuti i žal ljudi za onim vremenima u kojima razbijanje Srbije i Jugoslavije kao i svaka druga delatnost usmerena na rušenje ustavnog poretka nisu bivali čak ni u nijansama različito ocenjivani u republikama i pokrajinama“. IAB, 865, Gradski komitet, 45, 1983, 24. 10. 1983, Strogo poverljivo 001, Diskusija Ivana Stambolića, predsednika GK organizacije SK u Beogradu na 48. sednici Predsedništva CK SKS održane 19. oktobra 1983.

${ }^{42}$ IAB, 865, Gradski komitet, 45, 1983, 24. 10. 1983, Strogo poverljivo 018; AS, Đ-2, CK SKS, kutija 416, 1983, Materijali sa 49. sednice Predsedništva CK SKS, održane 27. oktobra 1983, Strogo poverljivo 002 .

${ }^{43}$ IAB, 865, Gradski komitet, 45, 1983, 24. 10. 1983, Strogo poverljivo 018, Uvodno izlaganje. 
Gradski komitet je dobio podršku Predsedništva CK SKS koje je posle dve sednice (27. oktobra i 1. novembra 1983) usvojilo Mišljenje o zaključcima Gradskog komiteta i uputilo ih saveznom partijskom Predsedništvu. U stavovima Predsedništva CK SKS je stajalo da je GK svestrano osvetlio implikacije događaja koji je imao „karakter svojevrsne političke demonstracije“. Srpski vrh je insistirao na kompleksnosti uzroka nezadovoljstava nalazeći ih u tome što se mnoga ključna pitanja razvitka društva sporo i nedosledno rešavaju u političkim i državnim organima i potencirajući da su u Beogradu kao milionskom gradu opterećenom „nizom specifičnosti“" u oblasti stambene i komunalne privrede, snabdevanja, bezbednosti, sva ta pitanja imala još veću političku težinu. ${ }^{44}$

U Predsedništvu CK SKS je bilo oštrih osuda kritike kojoj je savezni partijski vrh izložio beogradsku organizaciju i vlast. Radivoj Cvetičanin je kritikovao i „gorki cinizam“ kojim je Predsedništvo CK SKJ izjednačilo kontrarevoluciju na Kosovu i sahranu Rankovića pominjući oba događaja u kontekstu faktora iznenađenja. Vrlo oštrim rečima je vrednovao saveznu Informaciju da „tovari Beogradu na vrat i neke terete koji mu po mom mišljenju ne pripadaju (...) kao da je on središte birokratsko, dogmatsko, unitarističkih orijentacija i velikosrpskih i hegemonističkih aspiracija“. U takvom pristupu je video senku koja je iz davnih dana nadvijena nad srpskim komunistima kao da su oni „baštinisti monarhističke i karađorđevićevske istorije“. Drugačije je mislio Draža Marković koji je kao predsednik saveznog partijskog predsedništva bio mnogo kritičniji prema Gradskom komitetu, ne videći u njegovim zaključcima političku analizu događaja. ${ }^{45}$

Pitanje je skinuto sa dnevnog reda tek na sednici Predsedništva CK SKJ 22. novembra 1983, jer je Gradski komitet, podržan od Predsedništva CK SKS, i dalje bio nezadovoljan što je deo članstva SKJ imao Informaciju sa spornim pasusom. Dušan Čkrebić je sa tim stavom upoznao savezno rukovodstvo. Problem je rešen tako što je poslato pismo republičkim i pokrajinskim komitetima kojim su obavešteni o brisanju poslednjeg pasusa iz Informacije ,radi ukazanih mogućnosti da se taj stav pogrešno tumači“. Kompromisnom rešenju je prethodila duga diskusija u kojoj su ponovljeni stari stavovi. Nikola Stojanović, Hamdija Pozderac, Josip Vrhovec, Jure Bilić, Ali Šukrija i Petar Matić nisu odustajali od kritike Gradskog komiteta Beograda. Petar Matić je bio najoštriji. Pitao je: „Šta u stvari Gradski komitet hoće od Predsedništva? Da mu se izvinimo što nismo rekli da smo i mi odgovorni nego je on odgovoran za ono što se desilo u Beogradu?“. Optužio je beogradsko komunističko rukovodstvo za „nesamokritičnost“. Isti smisao je imala optužba koju je Bilić izneo da je GK zauzeo „odbranaški“ stav. Milan Kučan je imao razumevanja za prigovore činjenici da su u SKJ kružile dve različite verzije informacije i za zahtev za brisanje poslednjeg pasusa, ali nije prihvatao ton obraćanja Gradskog komiteta iz koga je sledilo utisak da je za stanje

\footnotetext{
${ }^{44}$ AS, Đ-2, CK SKS, kutija 417, 1983, Materijali sa 50. sednice Predsedništva CK SKS, održane 1. novembra 1983, Stavovi...; AS, Đ-2, CK SKS, kutija 417, 1983, Materijali sa 52. sednice Predsedništva CK SKS, održane 23. novembra 1983.

45 AS, Đ-2, CK SKS, kutija 416, 1983, Materijali sa 49. sednice Predsedništva CK SKS, održane 27. oktobra 1983, Strogo poverljivo 002.
} 
u društvu koje je dovelo do političke demonstracije na sahrani bilo odgovorno jugoslovensko rukovodstvo. Kučan je komplikovanom formulacijom stavio Srbiji na teret spekulacije u njenu privrženost društvenom sistemu. ${ }^{46}$

Političke razlike, pre svega između rukovodstva Srbije sa jedne, i političara iz pokrajina, BiH i Hrvatske, sa druge strane, time nisu prevaziđene. Narednih godina će dolaziti do izražaja kada budu zaoštrena pitanja odnosa Srbije i pokrajina, izdvajanja za nerazvijene, ekonomskog zaostajanja centralnog dela Srbije, odnosa prema političkim i ideološkim protivnicima i nepoželjnim pojavama itd.

$$
* * *
$$

Politički položaj Srbije u periodu posle smrti Josipa Broza bio je determinisan nastojanjima njenog rukovodstva da izmeni neravnopravan položaj u federaciji i zaustavi dezintegracione procese u republici koji su kontinuirano jačali posle Ustava iz 1974. Od ranije narušene političke odnose rukovodstva Srbije, sa jedne, i rukovodstava njenih pokrajina i pojedinih političkih krugova van Srbije, pre svega u BiH i Hrvatskoj, sa druge strane, dodatno je zaoštrilo nekoliko sporova tokom 1983. Neslaganja političara iz BiH, Hrvatske i pokrajine Vojvodine sa stavovima Dragoslava Markovića, koji je politički bio profilisan kao veliki zagovornik jedinstva Srbije, nisu sprečila njegov izbor, kao kandidata Srbije, za predsednika Predsedništva CK SKJ u 1983. Odnosi srpskog i hrvatskog rukovodstva su narušeni i objavljivanjem knjige Enigma Kopinič u Beogradu, čijem publikovanju se protivilo hrvatsko rukovodstvo zbog iznošenja za partiju nepoželjnih podataka iz međuratnog perioda i godina Drugog svetskog rata. Najveće podele je izazvalo tumačenje događaja na sahrani Aleksandra Rankovića (odgovornosti za masovnost i iskazano poštovanje prema pokojniku). Te događaje su savezni, republički i gradski partijski organi jedinstveno osudili kao političku demonstraciju protiv vlasti, ali se nisu slagali oko političke odgovornosti i uzroka javnog iskazivanja nezadovoljstva. Članovi Predsedništva CK SKJ iz autonomnih pokrajina i Hrvatske i BiH iskoristili su događaje na sahrani da optuže Srbiju i Savez komunista Srbije za srpski nacionalizam, a Gradski komitet SK Beograda za odgovornost što je došlo do političke demonstracije protiv vlasti. Za razliku od njih, Gradski komitet Beograda na čelu sa Ivanom Stambolićem, podržan od srpskog rukovodstva, smatrao je da je uzrok nezadovoljstva naroda ležao u ukupnoj političkoj, ekonomskoj i društvenoj krizi, za koju je bilo odgovorno rukovodstvo države.

\footnotetext{
46 „Srbija nosi jednu posebnu odgovornost što nije dovoljno (...) jasno opredeljena oko toga u kolikoj meri je za ovu situaciju u koju ulazimo kriv sistem, odnosno šta je posledica ovog sistema koji počiva na samoupravnom produkcionom odnosu i federativnom uređenju Jugoslavije“. AJ, 507, SKJ, Predsedništvo CK SKJ, 53. sednica 22. novembar 1983.
} 


\section{REFERENCE}

- Bela knjiga - 1984. Obračun sa ,kulturnom kontrarevolucijom “ u SFRJ. Priredili Kosta Nikolić, Srđan Cvetković, Đoko Tripković. Beograd: Službeni glasnik, 2010.

- Bjelajac, Mile. „Proizvođenje novih nacija, novih manjina i teritorijalna pitanja. (Koncept konkurentske države na tlu Srbije)“. The Shared History. Nations, States and Diasporas of the Former Yugoslavia (Nacije, države i dijaspora na prostoru bivše Jugoslavije). Urednik Darko Gavrilović, 121-142. Sremska Kamenica: Institute for Historical Justice and Reconciliation, Fakultet za evropske pravno-političke studije, 2010.

- Bjelica, Slobodan. "Views of Vojvodinian Leadership on Re-opening the Issue of the Relationship between SR Serbia and SAP Vojvodina in 1981". Istraživanja, br. 27, (2016), 258-273. https://doi.org/10.19090/i.2016.27.258-273

- Bjelica, Slobodan. „Vojvođanska autonomija - krizno žarište socijalističke Jugoslavije“. Kultura polisa, posebno izdanje Vojvodina kao potencijalno geopolitičko žarište u Republici Srbiji. Priredili Ljubiša Despotović i Goran Ivančević, 273-280. Novi Sad: Kultura - Polis, Institut za evropske studije, 2018.

- Cenčić, Venceslav. Enigma Kopinič. Beograd: Rad, 1983.

- Čkrebić, Dušan. Između pamćenja i zaborava. Memoarski i politički eseji. Novi Sad: Prometej, 2007.

- Čkrebić, Dušan. Pogled iskosa. Beograd: Službeni glasnik, 2009.

- Dimitrijević, Bojan. Ranković, drugi čovek. Beograd: Vukotić media, 2020.

- Dimić, Ljubodrag. Istorija srpske državnosti, III, Srbija u Jugoslaviji. Novi Sad: Srpska akademija nauka i umetnosti (ogranak u Novom Sadu), „Beseda“, izdavačka ustanova pravoslavne eparhije Bačke i Društvo istoričara južnobačkog i sremskog okruga, 2011.

- Đekić, Mirko. Upotreba Srbije. Optužbe i priznanja Draže Markovića. Beograd: Beseda, 1990.

- Đokić, Bojan. „Srpska javnost o međunacionalnim odnosima u Socijalističkoj autonomnoj pokrajini Kosovo 1981-1989“. Doktorska disertacija. Univerzitet u Novom Sadu, Filozofski fakultet, Odeljenje za istoriju, 2019.

- Đukić, Slavoljub. Kako se dogodio vođa. Borba za vlast u Srbiji posle Josipa Broza. Beograd: „Filip Višnjić“, 1992.

- Jović, Dejan. Jugoslavija - država koja je odumrla. Uspon, kriza i pad Četvrte Jugoslavije (1974.-1990.). Zagreb: Prometej, Beograd: Samizdat B92, 2003.

- Nikolić, Kosta. „Kako je Slobodan Milošević izabran za vođu srpskih komunista“. Istorija 20. veka, br. 1, (2006), 9-26.

- Nikolić, Kosta. „Kako je Slobodan Milošević izabran za vođu srpskih komunista (II)“. Istorija 20. veka, br. 2, (2006), 105-122.

- Petranović, Branko. Istorija Jugoslavije 1918-1988, III. Beograd: Nolit, 1988.

- Piljak, Milan. „Brionski plenum 1966. godine. Pokušaj istoriografskog tumačenja događaja“. Tokovi istorije, br. 1, (2010), 72-95. 
- Ristanović, Petar. Kosovsko pitanje 1974-1989. Novi Sad: Prometej, Beograd: Informatika, 2019.

- Selinić, Slobodan. „Formiranje albanske vlasti u Bujanovcu - pogled unazad“. Novi standard, 26. oktobar 2020: https://www.standard.rs/2020/10/26/formi ranje-albanske-vlasti-u-bujanovcu-pogled-unazad/

SLOBODAN SELINIĆ, PhD, Senior Research Fellow

Institute for Recent History of Serbia

Belgrade, Republic of Serbia

slobodanselinic@gmail.com

SERBIA AND POLITICAL RELATIONS IN YUGOSLAVIA DURING THE FUNERAL OF ALEKSANDAR RANKOVIĆ 1983: POINTS OF CONFLICT

\section{Summary}

Serbia's political status after the death of Josip Broz was determined by two kinds of efforts by the state. Firstly, the Serbian leaders aimed to change its unequal status in federal Yugoslavia. Secondly, they aimed to stop fragmentation within Serbia, which grew steadily after the 1974 Constitution. Political relations between Serbian leaders on the one hand, and some political circles and leaders of BosniaHerzegovina, Croatia, and the autonomous provinces on the other, were strained. They worsened even more after several clashes in 1983. Despite the opposition of politicians in Bosnia, Croatia, and Vojvodina to Dragoslav Marković (who was described as a strong advocate of Serbian political unity), he was elected as chairman of the Central Committee of the League of Communists of Yugoslavia (CK SKJ) in 1983. Serbo-Croatian relationships were further damaged after the publication of the book Enigma Kopinič in Belgrade. The Croatian leaders were against this publication because it revealed - as far as the Party was concerned - undesirable information about the interwar years and the period during World War II. The major confrontation came over the interpretation of events that occurred at the funeral of Aleksandar Ranković (mainly over who was responsible for the mass gathering and the respectful attitude toward the deceased). Federal party units, as well as those from the Yugoslav republics and from Belgrade, jointly condemned those events as a political rally against the government. However, they disagreed over who was responsible for the incident and what had caused the public outcry. The CK SKJ chairmanship members from the autonomous provinces, Croatia, and Bosnia accused Serbia and the Serbian Communist Party for the display of nationalism. They also held the Belgrade City Party Committee responsible for letting the rally happen. Contrary to this, the Belgrade City Committee led by Ivan Stambolić, whom the Serbian leadership supported, felt that the uproar was caused by the overall political, economic, and social crisis, for which the Federal government was to blame.

KEYWORDS: Serbia, Yugoslavia, Croatia, Bosnia-Herzegovina, Politics, Aleksandar Ranković, Ivan Stambolić, League of Communists of Yugoslavia 